\title{
IT'S NOT WORKING: BARRIERS TO THE INCLUSION OF WORKERS WITH MENTAL HEALTH ISSUES
}

\section{Tess Sheldon"}

This article examines the judicial treatment of complaints of discrimination from workers with mental health issues. Equality protections promise full inclusion in social, work and community life. The principle of inclusion is understood in three interrelated parts: inclusion in the workforce, inclusion in decisionmaking and, in the most broad and prospective sense, inclusion in Canadian society. The current framework of equality protections has not effectively addressed these core values of inclusion for workers with mental health issues. The workplace continues to be a site of discrimination and harassment. Barriers prevent workers with mental health issues from getting or keeping employment, discourage their participation in decisionmaking, and entrench the devaluation, isolation and exclusion of persons with mental health issues. Accommodative measures must be alive to the concrete and attitudinal barriers experienced by workers with mental health issues.

Cet article examine l'attitude adoptée par les tribunaux à l'égard des plaintes de discrimination des travailleurs ayant des problèmes de santé mentale. Les protections en matière d'égalité garantissent la pleine inclusion dans la vie sociale et communautaire et dans le marché du travail. Le principe d'inclusion comporte trois volets intimement reliés : l'inclusion dans le marché du travail, l'inclusion dans la prise de décision et, au sens le plus large et prospectif, l'inclusion dans la société canadienne. Le système actuel de protections en matière d'égalité n'a pas convenablement tenu compte de ces valeurs essentielles de l'inclusion des travailleurs ayant des problèmes de santé mentale. La discrimination et le harcèlement sont encore présents sur le marché du travail. Des obstacles empêchent les travailleurs ayant des problèmes de santé mentale d'obtenir un emploi et de le conserver, les dissuadent de participer aux prises de décisions et perpétuent la dévalorisation, l'isolement et l'exclusion des personnes ayant des troubles de santé mentale. Les mesures d'adaptation doivent tenir compte des obstacles concrets et comportementaux que doivent surmonter les travailleurs ayant des problèmes de santé mentale.

\footnotetext{
Staff Lawyer, ARCH Disability Law Centre. Ph.D. Candidate. Health and Behavioural Sciences,
} Dalla Lana School of Public Health, University of Toronto 


\section{INTRODUCTION}

It is a common misconception that mental health issues are life-long. Too often, people are told that a psychiatric diagnosis means certain deterioration. ${ }^{1}$ A recovery-oriented system, however, goes beyond symptom reductions and focuses on improving quality of life. ${ }^{2}$ While persons with mental health issues may continue to experience symptoms, research has demonstrated that many people with mental health issues are able to return to work. ${ }^{3}$

The stigma of mental health issues, however, remains a barrier to those who want to participate in the workplace. As a consequence of de-institutionalization and scarce health resources, persons with mental health issues are released from hospitals to the care of inadequate community supports and services and, as a result, may fall "through the cracks," onto the streets or into prisons. Persons with mental health issues are particularly subject to high levels of discriminatory treatment. Indeed, the Supreme Court has recognized the discrimination faced by persons with mental health issues:

There is no question but that the mentally ill in our society have suffered from historical disadvantage, have been negatively stereotyped and are generally subject to social prejudice.

This article focuses specifically on the rights situation of persons with mental health issues in the employment context and is organized as follows. The second section introduces important principles of the protection from discrimination for persons with mental health issues: substantive equality, accommodation, and undue hardship. The third section outlines how three parts of the principle of inclusion should guide how we conceptualize complaints of discrimination from workers with mental health issues. The fourth section addresses the barriers to the inclusion of workers with mental health issues.

\section{GENERAL ANTI-DISCRIMINATION PRINCIPLES}

Most rights protecting instruments in Canada, including the Charter of Rights and Freedoms ${ }^{5}$ and the Ontario Human Rights Code, ${ }^{6}$ set out mental disability as

1 Barbara Everett et al., Recovery Rediscovered: Implications for the Ontario Mental Health System (Toronto: CMHA Ontario, 2003), online: CMHA, <http://www.ontario.cmha.ca/content/ mental_health_system/recovery.asp?cID=3739 >.

Government of Canada, The Human Face of Mental Health and Mental Illness in Canada 2006

(Ottawa: Minister of Public Works and Government Services, 2006), online: Public Health Agency of Canada < www.phacaspc.gc.ca/publicat/ human-humain06/index-eng.php > at 47.

3

Honourable Michael Kirby, Out of the Shadows at Last: Transforming Mental Health, Mental Illness and Addiction Services in Canada (Ottawa: Standing Senate Committee on Social Affairs, Science and Technology, May 2006), online: Government of Canada <http://www.parl.gc.ca/ 39/1/parlbus/commbus/senate/Com-e/SOCI-E/rep-e/rep02may06-e.htm > at 42.

$4 \quad$ R. $v$ Swain, [1991] 1 S.C.R. 933 (S.C.C.) at 994. See also Nova Scotia (Workers' Compensation Board) v Laseur, [2003] 2 S.C.R. 504 (S.C.C.) at para 90, where the Court recognized that persons with mental disabilities have suffered considerable historical disadvantage and stereotypes. Chief Justice Lamer stated: "The mentally ill have historically been the subjects of abuse, neglect and discrimination in our society. The stigma of mental illness can be very damaging." 
an impermissible ground of discrimination. Courts have characterized human rights legislation as "fundamental" and "quasi-constitutional" and have directed that the provisions of such legislation be interpreted broadly and purposefully. ${ }^{7}$ In McConnell $v$ Yukon, the respondent argued that there is no need to accommodate mental disability given that Section 8.1 of the Yukon Human Rights Act requires accommodation only in the case of "physical disability." respondent's argument and held that human rights legislation must be given a large and purposive reading.

Even though such protection is set out in law, it may not have practical effect. Discrimination against people with mental health issues persists and the use of epithets such as "crazy" or "loony" remain commonplace." Some theorists hypothesize that because human rights jurisprudence has been developed in the context of race and sex, it fails to capture discrimination on the basis of disability, especially mental health. ${ }^{10}$

\section{A. Substantive Equality}

Recognition of the importance of substantive equality is a first step to understanding discrimination in the workplace against persons with mental health issues. In contrast to formal equality, substantive equality is concerned with the actual distribution of resources, opportunities and choices within a society. ${ }^{11}$ While rules, policies, procedures, requirements, eligibility criteria or qualifications may appear neutral, they may, nonetheless, amount to constructive or "adverse effect" discrimination. ${ }^{12}$ For instance, zero-tolerance policies about attendance may disproportionately impact workers with mental health issues.

5 Canadian Charter of Rights and Freedoms, Part I of the Constitution Act, 1982, being Schedule B to the Canada Act 1982 (U.K.), 1982, c.11 [Charter]. Section 15(1) of the Charter sets out that "[e]very individual is equal before and under the law and has a right to the equal protection and equal benefit of the law without discrimination and, in particular, without discrimination based on ... mental or physical disability".

6 Human Rights Code R.S.O 1990, c.h.19, s.10 [Code]. Section 10 of the Code sets out that disability means, amongst others, "a mental disorder".

7 O'Malley v Simpson-Sears Limited, [1985] 2 S.C.R. 536. Justice McIntyre stated for the court: "The accepted rules of construction are flexible enough to enable the Court to recognize in the construction of a human rights code the special nature and purpose of the enactment (see Lamer J. in Insurance Corporation of British Columbia v Heerspink, [1982] 2 S.C.R. 145, at 157ff), and give to it an interpretation which will advance its broad purposes. Legislation of this type is of a special nature, not quite constitutional but certainly more than the ordinary -- and it is for the courts to seek out its purpose and give it effect."

$8 \quad$ McConnell v Yukon (Public Service Commission), [1998] Y.H.R.B.A.D. No. 1 at para 37 (Yukon Human Rights Board of Adjudication).

9 Elizabeth Emens, "The Sympathetic Discriminator: Mental Illness, Hedonic Costs, and the ADA" (2006) 93 Geo LJ at 399. Emens noted: "Social discrimination against people with mental illness is widespread. Treating people differently on the basis of mental illness does not provoke the same moral outrage as that inspired by differential treatment on the basis of race, sex or even physical disability."

10 Ibid at 400

11 Anne Bayefsky, "Defining Equality Rights" in A. Bayefsky \& M. Eberts eds, Equality Rights and the Canadian Charter of Rights and Freedoms (Toronto: Carswell, 1985) 1 at 1. Bayefsky described equality of results as "a principle requiring action, which will achieve more equality in resources and rights. Equality of results will sometime require inequality of opportunity."

2 Code, supra note 6 at s. 11. 
The Supreme Court has described adverse effects discrimination as the manifestation of discrimination most often experienced by persons with disabilities. ${ }^{13}$ In Andrews v. Law Society of British Columbia, Justice McIntyre expressly recognized that "the accommodation of differences...is the essence of true equality." ${ }^{14}$ Justice McIntyre adopted the observation from Justice Dickson (as he then was) in R.v. Big M Drug Mart Ltd., that "the interests of true equality may well require differentiation in treatment." ${ }^{15}$

Human dignity is also a key element to the Supreme Court's understanding of discrimination. Justice Iacobucci in Law v. Canada (Minister of Employment and Immigration) described the overall purpose of section 15 of the Charter as the prevention of the violation of essential human dignity through the imposition of disadvantage, stereotyping or prejudice.

The traditional approach to the discrimination analysis required that tribunals characterize the issue as either "direct discrimination," where the standard is discriminatory on its face, or "adverse effect discrimination," where the facially neutral standard discriminates in effect. However, the Supreme Court in Meiorin, developed a unified approach to applying the tests for "direct discrimination" and "adverse effects" discrimination. ${ }^{17}$ In Grismer, the Supreme Court of Canada found the holding in Meiorin applies to all claims for discrimination. ${ }^{18}$

\section{B. Accommodation, Generally}

Appropriate accommodation can mean the effective return to work for people with mental health issues including the successful reintegration into the workplace after a mental health related absence. ${ }^{19}$ However if accommodation practices are not genuinely inclusive, an employee with a mental health issue may be perceived as a recipient of favouritism or special treatment. She may be subject to feelings of resentment, or be a victim of harassment by other employees. Managerial support is crucial for successful workplace accommodation. It can set the tone for how well accommodation will be accepted within a work unit.

Recipients of accommodative measures may be constructed as different, dependent and in need of charity. Day and Brodsky, as cited by the Court in Meiorin, argued that the principles of accommodation do not challenge the imbalances of power, and undermine the promise of substantive equality. ${ }^{20}$ They maintain that accommodation cannot address the underlying social structures at

13 See e.g. Eldridge v British Columbia (Attorney General), [1997] 2 S.C.R. 624; and British Columbia (Superintendent of Motor Vehicles) v British Columbia (Council of Human Rights), [1999] 3 S.C.R. 868 [Grismer].

9 Mental Health Works, Mental Health Works: Complex Issues, Clear Solutions - Participant Guide (Toronto: Canadian Mental Health Association, Ontario Division, 2007) at 1 [Mental Health Works Participant Guide]. 
the root of equality claims as long as the formal standard remains intact. ${ }^{21}$ Accommodation remains entrenched in the formal model of equality; while "likes" are treated alike, those who are "different" are treated differently.

Despite the dangers of its mainstreaming effects, the notion of accommodation is still useful. Well-developed accommodation efforts may indeed transform attitudes in the workplace. ${ }^{23}$ The Council of Canadians with Disabilities agreed, and pointed out that the courts have begun to interpret accommodation as a process for transforming majoritarian values into norms that are more inclusive of all abilities. ${ }^{24}$

The essence of accommodation is individualization. ${ }^{25}$ In Martin, the Supreme Court of Canada confirmed the need to take an individualized approach to the accommodation of persons with disabilities. ${ }^{26}$ There are a "virtually infinite variety" of disability related needs. ${ }^{27}$ Employers must tailor accommodations to an employee's particular needs and abilities. Indeed, Day and Brodsky argued that complainants with disabilities have an increased claim for individualization. ${ }^{28}$ Furthermore, because persons with mental health issues have periods of ability and disability, employers should evaluate requests for accommodation on a case-bycase basis. ${ }^{29}$ In particular, policies for the accommodation of employees with

21 Shelagh Day \& Gwen Brodsky, "The Duty to Accommodate: Who Will Benefit?" (1996) 75 Can Bar Rev 33 at 462. The authors continued: "It allows those who consider themselves "normal" to continue to construct institutions and relations in their image, as long as others, when they challenge this construction are 'accommodated'."

22 Ibid. The authors add, "Accommodation seems to mean that we do not change procedures or services. We simply "accommodate" those who do not quite fit. We make some concessions to those who are "different", rather than abandoning the idea of "normal" and working for genuine inclusiveness..."

23 Jerome Bickenbach, Physical Disability and Social Policy (Toronto: University of Toronto Press, 1993 ) at 237. Bickenbach described accommodation as a "necessary condition of political equality".

24 Yvonne Peters, "Twenty Years of Litigating for Disability Equality Rights: Has it Made a Difference? An Assessment by the Council of Canadians with Disabilities" (Winnipeg: CCD, 2004), online: CCD <http://www.ccdonline.ca/publications/20yrs/20yrs.htm\#IIIB1ciii>.

25 Ontario Human Rights Commission, Policy and Guidelines on Disability and the Duty to Accommodate (Toronto: Queen's Printer, 2000), online: OHRC < www.ohrc.on.ca $>$ [Duty to Accommodate] at 13.

26 Nova Scotia (Workers' Compensation Board) v Martin; Nova Scotia (Workers' Compensation Board) v Laseur, [2003] 2 S.C.R. 504 at para 81. The Court set out that "[t]he question, in each case, will not be whether the state has excluded all disabled persons or failed to their needs in some general sense, but rather whether it has been sufficiently responsive to the needs and circumstances of each person with a disability."

27 Ibid. The Court continued at para 18, "[d]ue sensitivity to these differences is the key to achieving substantive equality for persons with disabilities."

28 Day \& Brodsky, supra note 21 at 462 . The authors stated: "Because of the wide range of abilities... and the particularity of (dis)ability, individual accommodation, such as customizing a work site to suit the capacities of a person with a particular manifestation of a particular (dis)ability, is vital to the equality project."

29 Meiorin, supra note 17. At para 64, Justice McLachlin found: "The skills, capabilities and potential contributions of the individual claimant and others like him or her must be respected as much as possible. Employers, courts and tribunals should be innovative yet practical when considering how this may best be done in the particular circumstances." [emphasis added]. 
physical disabilities cannot be bluntly applied to the accommodation of employees with mental health issues.

The need for individualized attention is particularly evident in cases of intersectional discrimination. ${ }^{31}$ In such cases, there is a combination of various oppressions, which, together, produce something unique and distinct from any one form of discrimination standing alone. ${ }^{32}$ For instance, persons of colour with mental health issues may experience particular forms of discrimination in the workplace. ${ }^{33}$ Research has demonstrated that members of racialized communities are more likely to be identified by psychiatrists as "dangerous offenders." ${ }^{34}$

\section{Undue Hardship}

The onus of proof initially resides with the party alleging discrimination to make out a prima facie case of discrimination. ${ }^{35}$ The burden of persuasion requires proof on a balance of probabilities that the ground alleged was one factor in the respondent's conduct. ${ }^{36}$ Where the complainant makes out a prima facie case of discrimination $^{37}$, the respondent may avoid liability by establishing that the requirement is a "bona fide occupational requirement"[BFOR]. In Meiroin, the Supreme Court of Canada set out a three-step test to assess the requirement. First, the employer must demonstrate that she adopted the standard for a purpose rationally connected to the performance of the job. Second, the employer must establish that she adopted the particular standard in an honest and good faith belief that it was necessary to the accomplishment of a work-related purpose. Third, the employer must establish that the standard is reasonably necessary to the fulfillment of that legitimate work-related purpose.

30 See Gibbs v Battlefords and District Co-operative Ltd., [1996] 3 S.C.R. 566. An insurance policy provided that if a claimant had a mental illness, her replacement income would terminate after two years. If an employee was unable to work because of a physical disability, she was provided with replacement income for as long as the disability prevented the employee from working, or until age 65. The Supreme Court found that the plan treated people differently based on the type of disability they had.

Nitya Iyer, "Categorical Denials: Equality Rights and the Shaping of Social Identity" (1993) 19 Queen's LJ 179.

32 Ontario Human Rights Commission [OHRC], An Intersectional Approach to Discrimination (Toronto: Queens Printer, 2001), online: OHRC < http://www.ohr-c.on.ca/english/ consultations/ intersectionality-discussion-paper_1.shtml> [OHRC Intersectional Approach].

Ibid. Persons of colour with disabilities face challenges beyond those faced by other persons with disabilities with respect to access to housing and employment.

34 See generally Suman Fernando et al., Forensic Psychiatry, Race and Culture, (Boston: Routledge, 1998). See also R. Littlewood \& M. Lipsedge, Aliens and Alienists: Ethnic Minorities and Psychiatry (New York: Routledge, 1989). Littlewood and Lipsedge described the racial prejudices that pervade both in the theory and practice of psychiatry, which has resulted in inadequate treatment of patients from ethnic minorities. A prohibited ground of discrimination need only be one factor as opposed to the sole factor.

37 O'Malley, supra note 7 at para 28. Justice McIntyre set out as follows: "A prima facie case in this context is one which covers the allegations made and which, if they are believed, is complete and sufficient to justify a verdict in the complainant's favour in the absence of an answer from the respondent-employer" 
To demonstrate that a standard is reasonably necessary, it must be established that it is impossible to accommodate the claimant without imposing undue hardship upon the employer. In Renaud, the Supreme Court of Canada held that the term "undue" signifies that some hardship is acceptable and that more than a "mere negligible effort" is required to satisfy the duty to accommodate. ${ }^{39}$ In Grismer, the Supreme Court of Canada held that an employer must demonstrate that it considered and reasonably rejected all viable forms of accommodation. ${ }^{40}$

In the recent Hydro-Québec case, the Supreme Court clarified the third step of the Meiorin test. ${ }^{41}$ The Québec Court of Appeal held the dismissal of an employee with a long record of absenteeism related to her physical and mental health issues was discriminatory. Hydro-Quebec appealed the decision, arguing that the complainant was dismissed due to her inability to work on a "regular and reasonable" basis. At the Supreme Court, Justice Deschamps found that the Court of Appeal inaccurately interpreted the Meiorin decision, by requiring that HydroQuebec establish that it was impossible to accommodate the complainant's characteristics. Justice Deschamps clarified that the employer has only to demonstrate that it was impossible to accommodate an employee short of undue hardship, not that it was impossible to accommodate the employee at all:

The employer does not have a duty to change working conditions in a fundamental way, but does have a duty, if it can do so without undue hardship, to arrange the employee's workplace or duties to enable the employee to do his or her work...

If the characteristics of an illness are such that the proper operation of the business is hampered excessively or if an employee with such an illness remains unable to work for the reasonably foreseeable future even though the employer has tried to accommodate him or her, the employer will have satisfied the test.

The decision focuses on the limits of the employer's duty, rather than the scope, meaning and worth of the duty itself. In Hydro-Quebec, the Court offered no commentary on the extent and significance of disability, particularly mental health issues, in the Canadian workplace today.

A difficult question, especially from a business perspective, is when does accommodation become too expensive for the employer? The Supreme Court of Canada in Grismer held that "...one must be wary of putting too low a value on

39 Central Okanagan v Renaud, [1992] 2 S.C.R. 970 [Renaud] at para 19.

40 Grismer, supra note 13.

41 Meiorin, supra note 17 at para 54. The Supreme Court adopted a three-step test to determining whether an employer has established, on a balance of probabilities, that a prima facie discriminatory standard is a bona fide occupational requirement. The third step is: "To show that the standard is reasonably necessary it must be demonstrated that it is impossible to accommodate individual employees sharing the characteristics of the claimant without imposing undue hardship upon the employer."

42

Hydro-Québec v Syndicat des employé-e-s de techniques professionnelles et de bureau d'HydroQuébec, section locale 2000 (SCFP-FTQ), 2008 SCC 43 at paras 16 and 18. 
accommodating the disabled. It is all too easy to cite increased cost as a reason for refusing to accord the disabled equal treatment." ${ }^{43}$ The Ontario Human Rights Commission described a cost as "undue" if it is so high that it impacts the survival of the business or changes its essential nature. If the accommodation requires the business to fundamentally change what the business does, that may also be considered "undue." Clearly, different businesses have different financial circumstances: what may be an "undue cost" for a small business may not be undue for a larger one.

In Central Alberta Dairy Pool v. Alberta (Human Rights Commission), Justice Wilson of the Supreme Court of Canada reviewed factors relevant where the employee is no longer able to fulfill the basic obligations associated with the employment to the undue hardship analysis: financial cost, disruption of a collective agreement, problems of morale of other employees, interchangeability of workforce and facilities, the size of the employer's operation and safety. ${ }^{45}$ The Code, however, prescribes only three considerations in assessing whether an accommodation would cause an undue hardship: cost, outside sources of funding, and health and/or safety risks. ${ }^{46}$ Business inconvenience, resentment from other coworkers and customer preferences must be excluded from consideration in the accommodation process. ${ }^{47}$

\section{Procedural Obstacles}

One in five Canadians will experience mental illness during their lifetimes. More than ten per cent of Canada's adult population is living with one of five major mental health issues. ${ }^{49}$ Despite these staggering numbers, little judicial attention has been afforded to the human rights situation for persons with mental health issues. Procedural challenges prevent human rights tribunals from even hearing the claims of workers with mental health issues.

The number of complaints of discrimination to the Commission on the grounds of disability (both mental and physical) totalled about $56 \%$ of all complaints in 2006, exceeding complaints on other specific grounds protected by the Code. However, there are few Ontario Human Rights Tribunal decisions on complaints

43

44

Ontario Human Rights Commission, "Fact Sheet: How Far does the Duty to Accommodate Go?" online: OHRC, <http://www.ohrc.on.ca/en/resources/factsheets/disability4> [OHRC Fact Sheet]. The Ontario Human Rights Commission set out, "Such costs must be quantifiable and can include costs such as capital and operating costs and the cost of re-structuring. Human rights law recognizes that different businesses have different financial circumstances. What may be an 'undue cost' for a small business, may not be undue for a larger one."

45

Central Alberta Dairy Pool v Alberta (Human Rights Commission), [1990] 2 S.C.R. 489 at para 62.

47

Statistics Canada, Canadian Community Health Survey: Mental Health and Well-Being (Canada: Statistics Canada, 2003), online: Statistics Canada< http://www.statcan.ca/english/freepub/82617-XIE/index.htm>. online: OHRC <http://www.ohrc.on.ca/en/resources/annualreports>. 
citing the ground of "mental disability." Until June 2008, complaints are subjected to a very rigorous screening process by the Commission, which has the discretion to refer a case to the Tribunal for a hearing. ${ }^{51}$ Moreover, once a person filed a complaint, it may have taken years for the Commission to process the complaint. ${ }^{52}$ The recently introduced Human Rights Code Amendment Act, 2006, requires complaints of discrimination to be filed directly with the Tribunal rather than the Commission. ${ }^{53}$

There are several possible explanations for the lack of judicial attention afforded to the human rights situation for persons with mental health issues. Although human rights processes have become more legalistic and bureaucratic, complainants with mental health issues are unlikely to be able to afford counsel. In addition, a person with mental health issues may feel pressured to settle her complaint, especially in a complaint against a large corporate respondent. ${ }^{54}$ Complainants with mental health issues may also be subject to impoverished and/or inconsistent advocacy. As it is an emergent and unsettled area of law, it may be difficult for such complainants to access effective legal advice about the human rights protections guaranteed to them.

\section{E. Perceived Disability}

A prerequisite for a claim of discrimination is that the complainant must establish on a balance of probabilities that she had a disability at the time of the alleged discriminatory treatment. ${ }^{55}$ Mental health issues, however, are conceptually different from other types of disabilities in a number of ways. ${ }^{56}$ First, mental health issues are often invisible. No assistive devices, such as a wheelchair or a cane, typically identify a person with a mental health issue. Second, mental health issues are often episodic. Persons with mental health issues will experience symptoms

51 Ibid at 40. In 2006 - 2007, only $6 \%$ of all human rights complaints were referred to the Tribunal.

$52 \quad I$ bid at 14. In 2004-2005, most cases took more than 11 months to go through the initial process alone.

53 Human Rights Code Amendment Act, S.O. 2006, c. 30. After the Human Rights Code Amendment Act came into effect on June 30, 2008, the Ontario Human Rights Commission no longer accepted complaints of discrimination. All new applications alleging discrimination are filed with the Human Rights Tribunal of Ontario. Complaints that were filed with the Commission before June 30, 2008 may be re-filed with the Ontario Human Rights Tribunal.

54 Ian Morrison \& Janet Mosher, "Barriers to Access to Civil Justice for Disadvantaged Groups" in Ontario Law Reform Commission, Rethinking Civil Justice: Research Studies for the Civil Justice Review (Toronto: Ontario Law Reform Commission, 1996) 637 at 663 . The authors considered whether mediation processes are capable of taking account of the inequalities of resources. They find: "Subtle coercion may be pervasive within the mediation process because of the expectation of settlement and compromise. Voluntariness requires a real choice of options, adequate information about one's legal rights and entitlements and mechanisms that in some manner redress the inequalities of power." Mc Connell, supra note 8 at para 11.

56 Thomas Campbell \& Christopher Heginbotham, Mental Illness: Prejudice, Discrimination and the Law (Dartmouth: Vermont, 1991). At page 186, the authors stated: "The most crucial point is the differential treatment of mental illness compared with physical illness. Physical illness is often tolerated, sometimes to a considerable extent. Two or three days off for a flu or bad cold are quite acceptable. Three or four weeks off for a broken leg is tolerated - indeed it may invoke considerable sympathy. Three or four months off for glandular fever is unlikely to result in dismissal. The same periods away from work for an explicit mental illness are likely to lead to a demand for a psychiatric examination, great caution by management of promotion, discrimination in the type of work provided, and ultimately may lead to dismissal." 
cyclically, having periods of ability and disability. Also, the subjective experience of a particular mental health issue varies widely. Because no two people will experience a mental health issue in the same way, it is difficult to determine a standardized definition of disability and appropriate accommodations."

In order to prove that one has been discriminated against on the basis of mental disability, one must prove that she either has a mental disability or is perceived as having a mental disability. A mental health issue does not necessarily affect an employee's ability to do her work. She may nevertheless experience discrimination because others believe their disability makes them less able. An employer may assume that an employee is unable to perform the essential duties of her job when, in fact, her mental health issue raises no functional limitation.

The landmark decision of Québec (Commission des droits de la personne et des droits de la jeunesse) v. Montréal (City)) broadened the definition of "disability." ${ }^{58}$ In that case the three complainants were denied employment after pre-employment screening revealed medical conditions. All three complainants were at the time asymptomatic. The employers held that since there was no medical evidence of a functional limitation, the complainants were not entitled to seek protection on the ground of "disability." Writing for a unanimous Court, Madame Justice L'Heureux-Dubé supported a broad interpretation of the word "handicap" which includes conditions that do not cause functional limitations. ${ }^{59}$

The Ontario Human Rights Code and rights protecting instruments in other jurisdictions protect against discrimination on the basis of "perceived disability". In Mellon v. Human Resources Development Canada, the Tribunal applied a broad test to determine whether the complainant had a disability for the purposes of the Canadian Human Rights Act. ${ }^{61}$ The Tribunal offered the following comments on the nature of disability:

The Act does not contain a list of acceptable and unacceptable mental disabilities. It is not just the most serious or most severe mental disabilities that are entitled to the protection of the Act. Additionally, it is not solely those that constitute a permanent impairment that must be considered. Where appropriate, even mental disabilities described as minor with no permanent manifestation could be entitled to the protection under the Act. However, sufficient evidence still needs to be presented to support the existence of the disability. ${ }^{62}$

Gareth Williams, "Theorizing Disability" in G. Albrecht, K. Seelman \& M. Bury, eds, Handbook of Disability Studies (Thousand Oaks, CA: Sage Publications Inc., 2001) at 123. Williams set out that "the social reality of disability is one of considerable variation in the experience of impairment by large numbers of people who nonetheless share common conditions of exclusion, marginalization, and disadvantage." [2000] 1 S.C.R. 665 [Mercier].

Ibid.

Code, supra note 6 at s. 10(3).

61 Mary Mellon v Human Resources Development Canada (2006), C.H.R.T. 3 (Canadian Human Rights Tribunal). At para 81, the Tribunal provided that “... [a] disability may exist even without proof of physical limitations or the presence of an ailment". 
The emphasis, then, is on the effect of the distinction and not the proof of the alleged disability. These provisions protect workers with mental health issues in two ways. First, persons who have recovered from mental illness may continue to be treated unfairly because of their past condition. A survivor of the psychiatric system may still experience stigma even where she has not experienced psychiatric symptoms for some time. Second, persons with mental health issues are not always in need of accommodation because mental illness is episodic and temporary in nature. Persons with mental health disabilities are rarely continuously disabled, often having periods of ability and disability. ${ }^{63}$

The role of perceived disability in the discrimination analysis de-emphasizes the value of a psychiatric diagnosis. The Code's protection of presumed and perceived disabilities, coupled with the Mercier holding, focuses the analysis upon society's response to real or perceived limitations. It is sensitive to the phenomenon of "social handicapping" and the social models of disability in that a person may have no functional limitations other than those created by prejudice, stigma and stereotype. ${ }^{64}$ It recognizes that social attitudes alone can constitute disability and, in doing so, advances the goal of inclusion. ${ }^{65}$

\section{A TAXONOMY OF THE PRINCIPLE OF INCLUSION}

The desire for belonging is at the heart of all equality claims. ${ }^{66}$ The core value of "inclusion" should guide the interpretation of equality protections for persons with mental health issues in the workplace. Here, the three inter-related principles of inclusion are considered: inclusion in the workforce, inclusion in decisionmaking and, in the most broad and prospective sense, inclusion in Canadian society.

\section{A. Inclusion in the Workplace}

Exclusion in the context of employment merits particular attention, given that work is of central importance, including for persons with mental health issues. Finding and maintaining employment is a source of self-esteem ${ }^{67}$ and social relationships. ${ }^{68}$ It also provides access to choices about where to live. ${ }^{69}$ It affords a

63 Ibid.

64 See generally Bickenbach, supra note 23.

65 Ena Chadha, "The Social Phenomenon of Handicapping" in Elizabeth Sheehy, ed, Adding Feminism to Law: The Contributions of Justice Claire L'Heureux-Dubé (Toronto: Irwin Law, 2004) 209-227.

66 W. Pentney, "Belonging: The Promise of Community -- Continuity and Change in Equality Law 1995-96" (1996), 25 C.H.R.R. C/6. The author added: "Yet we know that communities are built in two ways: by welcoming and by keeping out."

67 D. M. Linhorst, Empowering People with Severe Mental Illness: A Practical Guide (Oxford: Oxford University Press, 2005) at 203. The author asserted that "[i]n our society we define ourselves as well as others by what we do - our work. Work is an essential element of our participation and acceptance in our community."

68 Lana Frado, Diversity Works: Accommodations in the Workplace for People with Mental Illness (Ottawa: CMHA Ontario, 1993). online: CMHA < www.cmh-a.ca/data/1/rec_docs/437_ diversity_works_final.pdf $>$ at 5 .

69 Julie Flatt, Hangin' In There: Strategies for job Retention by Persons with a Psychiatric Disability (Ottawa: CMHA, 2000), online: CMHA<www.marketing-island.com/ mi/tmm/en/ catalogue-manager/pdf0/C-M-H-A_hangin_in_there_EN.pdf> at 11 . 
variety of lifestyle and consumer choices by building financial independence. ${ }^{70}$ Employment is also important to recovery.

The unemployment rate of persons with mental health issues has been reported to range from $70-90 \%{ }^{72}$ Data from the United Kingdom found that one third of persons with mental health issues had been dismissed or forced to resign from their jobs. ${ }^{73}$ Research demonstrates that employers are as likely to hire persons with mental health issues for a retail sales job as "ex-convicts" or "marginally adjusted individuals;" the only group whom employers are more reluctant to hire are people with active tuberculosis.

The "intrinsic" value of persons with disabilities, especially persons with mental health issues, is often overlooked. ${ }^{75}$ Their identity is viewed as "defective." Various employment obstacles face persons with mental health issues. Some of these barriers act at the outset of potential employment and prevent a person with a mental health issue from even getting an interview. Persons with mental health issues often have periods of ability and disability and, consequently, may have sporadic or limited work histories. ${ }^{77}$ As a result, employers may assume that any employment gaps indicate that an employee is not capable or lazy. Employees with mental health issues may also be particularly vulnerable to the effects of restructuring, as employers may see it as a chance to get rid of problem employees. ${ }^{78}$

\section{B. Inclusion in Decision-Making}

Inclusion must promote capacity, choice and self-expression. It does not amount to non-interference, and instead may require the provision of support and

$$
\text { it Wort }
$$
it Working?' (1998) 16 Windsor YB Access Just 155 at 172. Lepofsky submitted that the aim of equality theory is to have people "fairly and accurately judged on their individual ability, based on what they can do in a barrier free context, and not on what they cannot do or on what others think they cannot do".

Frado, supra note 68 at 12.

See e.g. King v CDI Career Development Institute (2001), 39 C.H.R.R. D/322 (Saskatchewan Board of Inquiry). The complainant alleged that her employer refused to continue to employ her because of her mental health issues. The employer asserted that she was dismissed from her employment as a result of restructuring. See also Morris v British Columbia Rail (2003), 46 C.H.R.R. D/162 (British Columbia Human Rights Tribunal) at para 239. The British Columbia Human Rights Tribunal found that "at least some part of the BCRail's motivation in choosing Morris as a target of that downsizing was the fact that he was disabled." 
assistance to enable self-reliance. ${ }^{79}$ Grant and Mosoff claimed that equality theory "focuses on enhancing the participation of persons with disabilities..." Participation requires control over important decisions, including those at work. Employees with mental health issues must be placed at the centre of all decisions about accommodation options and participate in decision-making.

In particular, accommodation should not be coercive. Indeed, accommodation is most effective where it is voluntary. A well-meaning manager, for example, may attempt to convince an employee to access psychiatric services under threat of job consequence. This type of accommodation is not inclusive and ultimately stands as a barrier to the equality project. Employees with mental health issues usually know the types of accommodations that they require. Consultation with employees, therefore, is an essential step for managers. Managers may redouble the experience of discrimination if they ignore the self-identified needs of employees with mental health issues.

\section{Societal Inclusion}

A powerful process of disability disadvantage is exclusion, which is fuelled by stereotypes and stigma. Exclusion from opportunities and privileges reinforces the perception of persons with mental health issues as the "other/outsider" and perpetuates the cycle of marginalization. ${ }^{81}$ The historical oppression experienced by persons with disabilities manifests in overlapping processes of stereotype, stigma, devaluation and exclusion. ${ }^{82}$ Bill Holder offered the following commentary:

The consequence of not being provided with accommodation will be for persons with disabilities, some form of social exclusion, which is a condition of inequality... When respondents allege undue hardship they are, concomitantly, also alleging that the social exclusion of a person with a disability is warranted in the circumstances.

79 Federal/Provincial/Territorial Ministers Responsible for Social Services, In Unison 2000: A Canadian Approach to Disability Issues (Ottawa: Human Resources Development Canada, 2000), online: Social Union, <http://socialunion.ca>. In Unison highlighted independence as the ability to assume responsibility for own well-being, having control over lives through access to required supports and the elimination of barriers that prevent full participation. Isabel Grant \& Judith Mosoff, "Disability and Performance Standards Under the Ontario Human Rights Code" (2002) 1 JL \& Equality 205 at para 7.

81 Ena Chadha \& C. Tess Sheldon, "Promoting Equality: Economic and Social Rights for Persons with Disabilities Under Section 15" (2004) 16 NJCL 27.

82 David Lepofsky, "A Report Card on the Charter's Guarantee of Equality to Persons with Disabilities After Ten Years - What Progress? What Prospects?" (1997) 7 NJCL 263. at para 268. Lepofsky describes various physical, social and attitudinal barriers experienced by persons with disabilities. The author added: "Persons with disabilities in Canada often and disproportionately experience serious socio-economic disadvantage... They are under-represented in society's mainstream, where upward mobility is most likely."

83 Bill Holder, "Accommodation of Disability in Ontario" (Toronto: ARCH Disability Law Centre, 2003), online: ARCH < http://www.arch- disabilitylaw.ca/publications/ CLE_Disability-LawPrimer.asp> at 25 [emphasis added]. 
Substantive equality promises the full inclusion of persons with disabilities in social, work and community life. ${ }^{84}$ It can help shape new positive social attitudes about persons with mental health issues. Pentney argues, "[e]quality law seeks to protect and promote belonging; to allow others in to the fold, and to encourage and cement our bounds of community." ${ }^{, 85}$ Inclusion in the workplace helps to overcome stereotypes and bias, and decreases discriminatory animus. Working together as equals can also improve attitudes to persons with mental health issues.

The transformative effect of inclusion operates in two ways. First, improving the workplace experience of an employee with a mental health issue leads to improvement in other areas of life, such as self-esteem, access to housing and social relationships. Second, accommodation efforts will foster an ethic of inclusion, which will benefit persons from other disadvantaged groups. It is a signal that employees with mental health issues are valued members of the workplace, paving the way for other persons with mental health issues or from other communities to enter the workplace. While some may argue that it is not the employer's responsibility to encourage these important social consequences, inclusion benefits everybody.

\section{OBSTACLES TO THE INCLUSION OF WORKERS WITH MENTAL HEALTH ISSUES}

This section describes how well the current framework of equality protections applies the core value of inclusion for employees with mental health issues. It explores specific situations and relationships in which complaints of discrimination commonly occur. It examines concrete examples of barriers to the inclusion of workers with mental health issues and, as such, relies on jurisprudence.

\section{A. Disclosure of Accommodation Needs by Employees}

Accommodation is a "multiparty endeavour" and requires the employee to share information about the nature, but not the specifics, of her mental health issue. She must also be willing to explore accommodation options with her employer. In Renaud, the Supreme Court of Canada raised the obligation of employees to bring to the attention of the employer the facts relating to the discrimination as well as their role in securing appropriate accommodation. ${ }^{87}$ The

84 Lepofsky, supra note 76. Lepofsky maintained that the goal of equality to people with disabilities “....is to ensure persons with disabilities full participation and inclusion in all rights, benefits, burdens and obligations available in society." [emphasis added].

Pentney, supra note 66

But see Emens, supra note 9. Emens contended that “...[c] [ontrary to the much-vaunted contact hypothesis that workplace integration increases liking and decreases discriminatory animus, then, integration of people with mental illness may instead give coworkers and employers more reason to want to avoid people with mental illness."

87 Renaud, supra note 39 at para $43 f f$. Justice Sopinka stated for the Court: "Along with the employer and the union, there is also a duty on the complainant to assist in securing an appropriate accommodation... This does not mean that, in addition to bringing to the attention of the employer the facts relating to discrimination, the complainant has a duty to originate a solution. While the complainant may be in a position to make suggestions, the employer is in the best position to determine how the complainant can be accommodated without undue interference 
inclusion of the complainant in the search for accommodation was also recognized in $O^{\prime}$ Malley.

However, a worker with mental health issues may not be diagnosed or aware of their mental health issues and, as such, will be unable to request accommodation. If a worker lacks insight into her disability-related needs, she would not be aware of her need for accommodation in the workplace. She may not recognize the onset of a mental health issue at that time. ${ }^{89}$ Indeed, it may take some time for her to recognize that she is living with a mental health issue.

Moreover, due to the reasonable fear of adverse treatment, persons with mental health disabilities may be reluctant to ask for accommodation. ${ }^{90}$ For instance, the complainant in Bonner v. Ontario (Ministry of Health) testified that he was unwilling to disclose his need for accommodation when his supervisor referred to psychiatric patients as "loonies." In the workplace, "hidden consumers" may never disclose their need for accommodation because of the social stigma associated with their mental health issue. ${ }^{92}$ She may also fear that her work will be subject to increased scrutiny, following disclosure of her mental health issues.

Cases including Williams v. Elty Publications Ltd. ${ }^{94}$ and Strauss v. Ontario (Liquor Licence Board) establish that there is an obligation on the employee to communicate the nature of her disability to her employer. ${ }^{95}$ In Gardinar v. British Columbia (Attorney General), the Canadian Human Rights Tribunal found that because a disability may not have an impact on an employee for long periods, the employer may be unaware of her disability: "Where the Respondent is not aware of the disabilities, and no accommodation is requested, the duty to accommodate is not triggered. ${ }^{96}$

However, case law has established the employer's duty to accommodate mental health issues even where the mental health issue has not yet been

in the operation of the employer's business... The other aspect of this duty is the obligation to accept reasonable accommodation."

88

O'Malley, supra note 7 at para 23. Justice McIntyre stated for the Court, "Where such reasonable steps, however, do not fully reach the desired end, the complainant, in the absence of some accommodating steps on his own part such as an acceptance in this case of part-time work, must either sacrifice his religious principles or his employment."

89 Holder, supra note 83 at 24.

90 Mind Out for Mental Health, Line Manager's Resource: A Practical Guide to Managing and Supporting Mental Health in the Workplace (London: Department of Health, 2003), online: Mindful Employer, <www.mindfulemployer.net/Line\%20Managers\%20Resource.pdf>.

Bonner v Ontario (Ministry of Health) (1992), 16 C.H.R.R. D/485 (Ontario Board of Inquiry) at 19.

92 Gibbs, supra note 30 at 15. The Supreme Court of Canada in Gibbs referred to the shame associated with mental illness: "Mental illness is one of the least understood and least accepted of all illnesses. It creates fear and stereotypical responses in people... For a great many people, such illnesses are shameful and embarrassing and as a result they are very reticent to stand up for their rights or to protest when injustice has been done to them".

93 Flatt, supra note 69 at 23.

94 Williams v Elty Publications Ltd. (1992), 20 C.H.R.R. D/52 (British Columbia Council of Human Rights) at para 69. In that case the behaviour of the complainant had not changed during her employment and, therefore, there was no basis for the complainant's submission "...that the respondent either knew or ought to have known of the complainant's disability".

95 Strauss v Ontario (Liquor Licence Board) (1994), 22 C.H.R.R. D/169 (Ontario Board of Inquiry).

96 Gardinarv British Columbia (Attorney General), [2003] B.C.H.R.T.D. 40 (British Columbia Human Rights Tribunal) at para 168. 
diagnosed. In United Steelworkers of America, Local 5885 v. Sealy Canada, the grievor was found not responsible for an altercation related to a manic episode of undiagnosed bipolar disorder. ${ }^{97}$ The arbitrator reinstated the grievor with the following explanation:

Where the evidence establishes that the Grievor's behaviour was the result of a previously undiagnosed medical condition, the nature of the act changes from one that is subject to automatic discharge with little possibility of reinstatement to one where the Grievor's rehabilitation and prognosis become crucial fact in the application of a remedy.

An applicant may worry that if she discloses the fact of her mental health issue, her employer will be reluctant to offer her employment opportunities. In Lane v. ADGA Group Consultants Inc, Lane did not reveal that he had been diagnosed with bipolar disorder before he was hired. Four days after starting work, he advised his immediate supervisor that he had been diagnosed with bipolar disorder. He requested that the supervisor alert his wife or doctor of symptoms of an impending manic or depressive episode. Very shortly after that meeting, Lane was dismissed. The Tribunal found that ADGA discriminated against Lane by summarily terminating his employment shortly after discovering that he had a mental health issue. The Tribunal held that if Lane had revealed this information, it would have likely triggered a stereotypical reaction about his ability to do the job, leading to a decision not to hire him and reluctance to explore accommodation options. ${ }^{99}$ Expert evidence at the hearing established that persons with bipolar disorder may be reluctant to reveal their disability to prospective employers. The Tribunal found that ADGA could not rely on Lane keeping his disability secret as a justification for dismissing him. ${ }^{100}$ The Ontario Divisional Court upheld the Tribunal's findings on this point.

While it is typically up to the employee to request accommodation, there are instances where a complainant may not be required to do so. For example, the complainant may not have been diagnosed or may not have been aware of her mental health issues. She may be unwilling to reveal her disability, anticipating

United Steelworkers of America, Local 5885 v Sealy Canada [2006] B.C.C.A.A.A. No. 23 (Alberta Grievance Arbitration) [Sealy].

Ibid at para 59.

99 Lane v ADGA Group Consultants (2007), C.H.R.R. Doc. 07-586, 2007 H.R.T.O. 34 (Ontario Human Rights Tribunal), aff'd [2008] O.J. No. 3076 (Ontario Superior Court of Justice). The Tribunal found at paras $144-5$, that " $[\mathrm{t}]$ he procedural dimensions of the duty to accommodate required those responsible to engage in a fuller exploration of the nature of bipolar disorder, Lane's own situation as a victim of bipolar disorder, and to form a better informed prognosis of the likely impact of his condition in the workplace."

100

Ibid. The Tribunal found that the failure to fulfill the procedural dimension of the duty to accommodate is a form of discrimination in its own right. This means that discrimination can occur when an employer fails to conduct an appropriate assessment to determine whether it can accommodate an employee's disability and when such a failure has adverse consequences to the employee.

101 Ibid. The Superior Court found at para 126ff: "The Tribunal thus found as a fact that ADGA failed to take any of the steps it could have taken in order to assess and pursue the question of accommodation. It held there was a 'rush to judgment' by ADGA." 
discriminatory reactions by her employer or coworkers. The relaxation of requirements to disclose a need for accommodation furthers the goal of inclusion by continuing to protect the right to freedom from discrimination for workers with mental health issues who are unable or unwilling to request accommodation.

\section{B. The Employer's Duty to Investigate an Undisclosed Need for Accommodation}

Some human rights tribunals have absolved the employer of responsibility where there is no reason for the employer to suspect that the employee has accommodation needs. In Kamloops/Thompson SD No. 73 v. British Columbia Teachers' Federation, a teacher presented a certificate to her employer indicating that she was under care for "a medical problem that has been precipitated by what she perceived to be an intolerable work environment." the grievor did not disclose her mental health issues or need for accommodation to the employer. The arbitrator found that there were no signs that would have led the employer to suspect that the grievor experienced a mental health issue: "without sufficient information an employer may not be able to accommodate to the extent expected by the grievor."

However, an employer may take advantage of a situation where an employee is unable (due to lack of insight) or unwilling (due to social stigma) to disclose the fact of her disability. The employer may want to terminate the employment of a "difficult" employee. However, even where an employee does not alert the employer to her disability-related needs, the employer may be presumed to have knowledge of the disability. The employer may be considered to have received constructive notice of the need for accommodation. ${ }^{104}$

Other tribunals have found that if an employee does not disclose her mental health issues she is not necessarily disentitled from human rights protection. In Mager v. Louisiana-Pacific Canada Ltd, the complainant informed her employer that she was having trouble eating and sleeping, that she hated her life, that she was not her normal self and that she was extremely depressed. Under pressure, the employee agreed to be laid off. The respondent refused to re-employ her when she asked to return to work. The Tribunal found that the respondent-employer "ought to have known that she was not medically fit." ${ }^{105}$ The British Columbia Human Rights Tribunal summarized the situation:

I find that [the employer] knew, or ought to have known, that the complainant was in extreme emotional distress and, as a result, disabled from doing her job. She told him as much when she met with him in mid-May. The fact that she did not present him with

102 Kamloops/Thompson SD No. 73 v British Columbia Teachers' Federation, [2005] B.C.C.A.A.A. No. 39 (British Columbia Collective Agreement Arbitration).

103 Ibid at para 54 [emphasis added].

104 Holder, supra note 83 at 23. Holder provided that “...[w]hen an employer terminates an employee with an apparent but undisclosed mental health disability due to unusual behaviours exhibited by the employee, the employer runs the risk of having constructive knowledge of the employee's mental health disabilities imputed to it".

105

Mager v Louisiana-Pacific Canada Ltd. (1998), 33 C.H.R.R. D/457 (British Columbia Human Rights Tribunal) at para 63. 
a medical diagnosis does not disentitle the complainant to the protection of the Code. ${ }^{106}$

As set out in the previous section, stigma may prevent an employee with mental health issues from requesting accommodation. In Willems-Wilson $v$. Allbright Drycleaners Ltd., the Tribunal held that the respondent-employer fired the complainant without giving her the chance to request accommodation. The complainant described to the Tribunal her reluctance to discuss her mental health status with her employer, given the social stigma associated with mental health issues. The Tribunal found that the complainant's failure to speak openly about her situation was not fatal to her complaint. Given all the information available to him, the employer should have made inquiries into her mental state. ${ }^{10}$

Tribunals have determined that in some cases employers have a responsibility to make inquires about the complainant's mental health issues. In Zaryski v. Loftsgard, the respondent-employer observed several of the complainant's emotional outbursts. He made the decision to terminate her employment before considering accommodation options. The Board concluded that the employer, after being informed by the complainant's husband that she had seen a doctor, "had a responsibility to at least inquire as to whether that fact might impact upon his decision." "108 His failure to do so was in contravention of Saskatchewan's Human Rights Code:

It is not enough for the respondents to say that they were not advised of or aware of the complainant's condition. Certainly the employer was aware that Ms. Zaryski was suffering from what might be described as a delicate emotional state. ${ }^{109}$

An employer, in some cases, may be required to make reasonable inquiries about the accommodation needs of an employee who requested "medical leave." In Sylvester v. British Columbia Society of Male Survivors of Sexual Abuse, the complainant did not inform her employer of her mental health issues. ${ }^{110}$ She did, however, inform the employer in writing that she needed to take a medical leave. The Tribunal found that the employee's letter should have precipitated inquiries from the employer, particularly since the employer admitted observing a change in the complainant's behaviour. The employer had a duty, at least, to inquire about the complainant's medical condition and to determine whether she could be accommodated. The Tribunal articulated:

In my view, the reasonable step for an employer to take when notified of a "medical" leave is make reasonable inquiries about the nature of the medical condition and the length of the leave to

\footnotetext{
106 Ibid at para 56. 
determine how the workplace would be affected and what accommodation, if any, was possible. The respondent failed to make these inquiries.

As set out by the case law, there may be situations in which an employer may be required to make proactive inquiries about an employee's disability related needs. This furthers the goal of inclusion in the workplace especially where a worker is unwilling or unable to request accommodation.

\section{Excusing Misconduct Related to a Mental Health Issue}

As with an employee without a disability, circumstances may arise where employers must determine whether to discipline an employee with a mental health issue. Employers may demonstrate poor tolerance of an employee's disabilityrelated behaviour, including emotional outbursts, missed deadlines or poor attendance. ${ }^{112}$ Employers may be reluctant to excuse misconduct attributable to an employee's mental health issue because they may fear charges of "special treatment" from co-workers. Critics may also claim that it is a "license to behave badly"." "113 From a business perspective, the difference between a "poor performer" and an employee in need of accommodation is difficult to discern.

Recent scholarship delineates competing approaches to the analysis of misconduct by workers with mental health issues. Professor Michael Lynk proposes three arbitral models that have been applied by arbitrators to grievances where a worker with a mental health issue has engaged in misconduct related to her disability. ${ }^{115}$ First, the "discipline" model conceives of the duty to accommodate as one factor in the determination of the appropriate discipline of a culpable employee. Secondly, the "disability" or "therapeutic" model posits that culpability is not relevant to the determination of whether the employer met her duty to accommodate the employee. Finally, the "hybrid" model balances consideration of the employee's culpability and the employer's duty to accommodate. Professor Lynk posits that while the three approaches remain "tangled," the hybrid approach is most commonly applied. The Arbitration Panel in Legal Aid Lawyers Association v. Manitoba (2009) elaborated on the three-part categorization:

The first approach is often referred to as the "disciplinary" model. ... Under the disciplinary model, if an employee is able to establish that he or she is suffering from an addiction, the

\footnotetext{
111 Ibid at para 40.

112 See e.g. L.B. (Committee of) v Newfoundland (Human Rights Commission), [2002] N.J. No. 187. The employer requested medical documentation after the complainant's absences from work. The complainant explained that the absences were due to a "chemical imbalance". The Court of Appeal found that employer did not dismiss the complainant because they thought that she was incapable performing her job. The Court found at paragraph 40 that her failure to provide medical documentation was not related to her disability. Ralph Slovenko, "Book Forum", Book Review of Mental Disorder, Work Disability and the Law by Richard Bonnie \& John Monahan, (1999) 155 American Journal of Psychiatry 985.

114 Ibid.

115 Michael Lynk, "How to Accommodate Mental Health Issues," (2006) 26 Lawyers Weekly (November 3, 2006)
} 
addiction will be treated as "mitigating" but not an exculpatory factor. ...

The therapeutic approach is at the opposite end of the spectrum... [U]sing this model, any employee conduct related to his or her addiction is treated as non-culpable, and therefore not subject to discipline. The primary emphasis under this model is treatment and rehabilitation, but will also usually involve an analysis of the extent to which an employer had accommodated the employee's disability. ...

The third approach has been referred to as the "hybrid" model...Such cases typically involve the imposition of a penalty upon the employee, such as a suspension, which is frequently combined with a series of strict conditions...

Arbitrators, relying on the "discipline" and "hybrid" approaches, generally uphold dismissals of employees with mental health issues who have engaged in misconduct. ${ }^{117}$ However, there is some jurisprudence reinstating employees with mental health issues. In Spawn v. Parks Canada Agency, the employer demoted an employee who had been found to have stolen gasoline. ${ }^{118}$ The complainant argued that depression impaired his judgment. While the arbitrator found that his actions were not an example of an irresistible impulse, he reinstated the complainant to a full time position:

His judgement was impaired but he knew that stealing was wrong. While his medical condition is a mitigating factor, it does not entirely excuse his conduct. His conduct warranted discipline but I find that demotion to a seasonal position is too severe in the circumstances. ${ }^{119}$

An employer must consider accommodation options before discharging an employee with a mental health issue for reasons of misconduct. In Proulx $v$ Canada Treasury Board, the employer ordered a 20-day suspension against an employee who threatened a co-worker. ${ }^{120}$ The arbitrator upheld the suspension

116 Legal Aid Lawyers Association v Manitoba (Fawcett Grievance) [2009] M.G.A.D. No. 6 at paras 58, 61 and 64 [emphasis added].

117 Canadian Association of University Teachers (CAUT), "Workplace Accommodation of Mental Disability: Tips from the Case Law" online: CAUT $<$ http://www.caut.ca/pages.asp?page $=493>$ ) at 3. The author provided: "A mental disability does not automatically excuse otherwise disciplinable conduct. There are two ways that a proven mental illness might affect discipline. 1) If the mental illness is so severe that it completely deprives the employee of the ability to form the intent to commit the offence; 2) If the mental illness is not so severe as to negative treatment, it may be taken into account as a mitigating factor when deciding the appropriate penalty." Spawn v Parks Canada Agency, [2004] C.P.S.S.R.B. No. 23 (Canada Public Service Staff Relations Board).

119 Ibid at para 288. The Board continued on to find, "[t]o be corrective, a sanction cannot be excessive."

120 Proulx v Canada Treasury Board, [2002] C.P.S.S.R.B. No. 35 (Canada Public Service Staff Relations Board). 
given that the employer took the employee's state of health into consideration as well as the seriousness of the impact upon the co-worker.

Other case law establishes that there must be a nexus between the employment offence and the mental health issue. ${ }^{121}$ In Thunder Bay (City) v C.A.W. (Local 229), an Arbitration Board held that expert medical evidence must establish a connection between the disability and the misconduct. ${ }^{122}$ The Board found that the grievor failed to provide evidence explaining the grievor's conduct by reason of disability. Evidence was required to meet the following four criteria. ${ }^{123}$ First, the union must establish that the grievor experienced a mental health issue. Second, there must be a link established between the mental health issue and the aberrant conduct. If there is a link, the arbitrator must be persuaded that there was a sufficient displacement of responsibility rendering the grievor's conduct less culpable. Finally, the arbitrator must be satisfied that the grievor has been rehabilitated.

A dismissal may be upheld where there is evidence that the misconduct will likely continue. In Amalgamated Transit Union, Local 113 v. Toronto Transit Commission, the Ontario Labour Board did not reinstate an employee with a mental health issue where there was evidence that his threats could not be "controlled". In Canada Safeway Ltd. and Retail, Wholesale and Department Store Union, the grievor did not deny stealing money from a cash register. ${ }^{125}$ She acknowledged that she knew what she was doing was wrong when she stole the money but that the depth of her despair caused her not to care. The Arbitration Board reinstated the employee, although the Saskatchewan Court of Appeal reversed that decision:

Her actions were premeditated and calculated. It may be that her psychological condition was the main contributor to her actions but it has not been established on a balance of probabilities that that was the case. More importantly, even if we accept that it was established, we have no confidence that the grievor has her situation currently under control. ${ }^{126}$

121 United Nurses of Alberta, Local $33 v$ Capital Health (Royal Alexandra Hospital) (O'Neill Greivance) [2008] A.G.A.A. No. 50. A nurse had been terminated following allegations of theft and use of narcotics. The arbitration panel considered whether the "evidence was sufficient to establish a causal link between Ms. O'Neill's thefts of the narcotics and her substance abuse and mood disorders". While the employee's treatment was found not to amount to discrimination pursuant to Alberta's Human Rights Act, her disability related needs were included as a "mitigating factor" at paragraph 57 of the panel's decision. The panel's decision is consistent with the "hybrid" approach (see for e.g. Lynk, supra note 115).

122 Thunder Bay (City) v C.A.W. (Local 229), [2005] O.L.A.A. No. 472 (Ontario Labour Arbitration).

123 Janice Payne \& Trevor Fenton "Accommodating Mental Illness in the Workplace: Principles and Practice" (September 2005), online: Nelligan, O’Brien, Payne LLP, <http://www.nelligan.ca/ e/pdf/Mental_Illness_Workplace.pdf> at 12.

124 Amalgamated Transit Union, Local 113 v Toronto Transit Commission (Collins Grievance) [2005] O.L.A.A. No. 743 (Ontario Labour Arbitration).

125 Canada Safeway Ltd. and Retail, Wholesale and Department Store Union (1999), 82 L.A.C. (4th) 1, aff'd [1999] S.J. No. 619 (Saskatchewan Court of Queen's Bench), rev'd [2000] S.J. No. 641 (Saskatchewan Court of Appeal).

126 Ibid at para 23 [emphasis added]. 
Generally, arbitrators, applying the discipline or hybrid approach, ${ }^{127}$ ask the question whether the employee or her behaviour can be "controlled," or whether they have been "rehabilitated." This language depicts workers with mental health issues as passive participants needing to be "controlled" or "fixed." It identifies disability as a physiological impairment ${ }^{128}$ and aspires to "cure" the disorder. Instead, the focus should shift from the biological impairments of disability to the significant role the social environment plays in "handicapping" individuals. Indeed a person may have no functional limitations other than those created by prejudice, stigma and stereotype. ${ }^{130}$ Employers are required to investigate if the misconduct is related to a mental health issue, which is, in itself, a difficult issue to determine and one that may require professional assistance. ${ }^{131}$ Even if the misconduct seems intolerable, the Code requires that the employer consider if continued tolerance would amount to undue hardship.

\section{Issues of Undue Hardship}

A complaint from an employee with a mental health issue may fail when a respondent establishes that she was unable to accommodate the complainant's disability-related needs, short of undue hardship. However, the application of the test for undue hardship often incorporates negative stereotypes about persons with mental health issues, including those related to dangerousness or ability to handle stress. ${ }^{132}$ For instance, it is a common misconception that persons with mental health issues are violent and, therefore, present a safety risk to the workplace. This myth is reinforced by media portrayals of people with mental health issues as frequently and unpredictably violent. However, data demonstrates that persons with mental health issues are more likely to be victims of violence than perpetrators of violence.

An employer must make individual determinations, invoking the three-part test for accommodation to the point of undue hardship, as established in O'Malley $v$. Simpsons Sears Ltd. ${ }^{134}$ The series of Gordy $v$. Painter's Lodge decisions involved a

127

128

Lynk, supra note 115

Day \& Brodsky, supra note 21 at 462 . The authors stated: "We do not view the human population as comprised of people with many different kinds and levels of abilities, which are more and less suited at different times to different tasks and opportunities. Instead, we tend to make a demarcation, based on statistically and medically defined ranges of 'normalcy', between the 'able' and the 'disabled'..."

129

Ian B. McKenna "Legal Rights for Persons with Disabilities in Canada: Can the Impasse Be Resolved?" (1997-1998) 29 Ottawa L Rev 153 at para 14. The traditional predominance of the biomedical model of disablement produces an exclusive and distorted focus on the differences between persons with disabilities and others in society labelled as non-disabled.

130 See generally Bickenbach, supra note 23.

131 CAUT, supra note 117 at 8 . The author provided: "Expert medical evidence is necessary to show the presence of a disability, and in cases of misconduct, to establish a connection between the disability and the misconduct".

132 Canadian Mental Health Association - Ontario Division, "Violence and Mental Illness: Fact Sheet", online: CMHA < http://www.ontario.cmha.ca/content/reading_room /factsheets.asp?cID $=4006>$.

133 Ibid. See also Frado, supra note 68 at page 4

134 O'Malley, supra note 7. 
complainant who worked as a guide for a fishing lodge in British Columbia. ${ }^{135}$ Gordy's employment was terminated after his employer discovered that he had been diagnosed with bipolar disorder. For the first time at the British Columbia Human Rights Tribunal, the employer took the position that it would constitute undue hardship for him to assume the safety risk of continuing to employ Gordy. The Tribunal found that the employer had erred in failing to conduct a further investigation as to whether or not Gordy could safely perform his duties. On judicial review, the Court of Appeal remitted the matter back to the Tribunal for a rehearing on the issue of whether Gordy had been accommodated to the point of undue hardship. The second Tribunal concluded that the employer had failed to meet its legal obligation to accommodate Gordy to the point of undue hardship.

Employers may rely on injurious stereotypes concerning persons with mental health issues and argue that they cannot hire, or continue to employ, anyone whose disability increases the probability of health or safety hazards to other employees or the public. The employer may argue that a person with a serious mental health issue may not be able to perform the essential duties of the job. The Code prescribes that health and/or safety considerations may be useful in considering whether an accommodation would amount to undue hardship. ${ }^{136}$

The duty to provide a safe workplace cannot displace the duty to accommodate. In an effort to ensure workplace safety, an employer may implement zero-tolerance anti-violence policies. ${ }^{137}$ The rigid application of such policies may disproportionately impact workers with mental health issues and amount to adverse-effect discrimination. Where the offending behaviour is linked to mental health issues, the employer's duty to accommodate arises. While the employer is not required to tolerate violent behaviour blindly, any disciplinary measures must take into account mental health issues.

Employees with mental health issues must be accommodated to the point of undue hardship even in the case where the employee poses a safety risk. In Shuswap Lakes General Hospital v. British Columbia Nurses Union, a labour arbitrator found that a nursing home, which had suspended a nurse with a bipolar disorder for making several medication errors, did not appropriately accommodate her. The arbitrator found that the hospital had failed to establish a "serious" or "unacceptable" risk to patient safety:

Many adjudicators have commented on the risk to safety and I find this is an area where the legal test has evolved over time. Now, in assessing what constitutes undue hardship where safety is an issue, a standard of "serious risk" or "unacceptable risk", as opposed to a "real risk" or a "minimal risk", must be satisfied.

\footnotetext{
135 Gordy v Oak Bay Marine Management Ltd. [2000] B.C.H.R.T.D. No. 15 (British Columbia Human Rights Tribunal), rev'd [2000] B.C.J. No. 2504 (British Columbia Supreme Court), rev'd [2001] B.C.J. No. 1136 (British Columbia Court of Appeal). See also Gordy v Oak Bay Marine Management Ltd. No. 2 (2004), 51 C.H.R.R. D/68 (British Columbia Human Rights Tribunal). 
The question of safety and the nature of risk has received some judicial attention. It is well settled that the standard is not one of "absolute safety" but of "reasonable safety." ${ }^{139}$ In Grismer, the Supreme Court held that "...risk has a limited role...":

It is clear from Meiorin that the old notion that "sufficient risk" could justify a discriminatory standard is no longer acceptable. Risk can still be considered under the guise of hardship, but not as an independent justification of discrimination. ${ }^{140}$

Relying on stereotypes of persons with mental health issues, employers may also cite concerns about an employee's ability to tolerate pressure in a hectic workplace. Employees may be routinely passed over for promotions and assumed to be unable to withstand the stressful periods in the workplace. ${ }^{141}$ In Communications, Energy \& Paperworkers' Union, Local 440 v. Kimberley Clark Nova Scotia, an application for judicial review was dismissed. ${ }^{142}$ An employee who had been laid off was not recalled for a job vacancy. The employer argued that that position was stressful and required a high degree of mental alertness. The arbitrator concluded that the refusal to recall the employee constituted discrimination, but that it was justified because the disability rendered him unable to perform the work.

Employers may also be reluctant to hire or continue to hire employees with mental health issues because of perceived security risks. In Stevenson v. Canadian Security Intelligence Service (CSIS), an intelligence officer requested that the relocation of his position be deferred, since it would exacerbate his mental health issues. ${ }^{143}$ The Tribunal found that once having received a negative medical assessment, CSIS made no attempt to accommodate his disability, such as reassessing whether it was necessary to relocate his employment.

Even where the position involves "mission critical" work, the employer is required to investigate accommodation options. In Lane v. ADGA Group Consultants Inc., a human rights tribunal ruled against an employer involved in contract government information technology services. ${ }^{144}$ The complainant's responsibilities included artillery software testing. A few days after his start date,

139 See in particular Health Employers Association of British Columbia v BCNU (Vroom), [2002] B.C.C.A.A.A. No. 236 (British Columbia Collective Agreement Arbitration).

140

Grismer, supra note 13 at para 30.

141 Frado, supra note 68 at 6 . The author provided: "Stress is a very individual response to specific situations. It is not true that people with mental illness cannot handle any stress. We all know that some stress has some positive effects, and what is stressful for you may not necessarily be stressful for your neighbour. Any one employee may work well on their own, or at a computer terminal, but may not be able to handle interpersonal relationships, group assignments, or the team approach very well. On the other hand, many people thrive on knowing that they are members of a team, and flounder when they are left to work on their own. The situation is the same for people with psychiatric disabilities."

142 Communications, Energy and Paperworkers' Union, Local 440 v Kimberley Clark Nova Scotia, [2000] N.S.J. No. 94 (Nova Scotia Supreme Court).

143 Stevenson v Canadian Security Intelligence Service (5 December 2001), No. TD 16/01(Canadian Human Rights Tribunal), appealed to the Federal Court Trial Division on grounds of remedy: Canada (Attorney General) v Stevenson (2003), 46 C.H.R.R. D/213, 2003 FCT 341. 
he told his supervisor that he had bipolar disorder and requested accommodation. ${ }^{145}$ Lane's employment was terminated very shortly thereafter. ADGA alleged he was dismissed because he was not capable of performing the essential functions of the job for which he had been hired. The Tribunal determined that ADGA terminated Lane's employment because of his disability and the employer's perceptions of his disability. The supervisor based the decision to terminate Lane's employment solely on his personal assessment, without investigation into the nature of his mental health issues or of possible accommodations within the workplace. ${ }^{146}$ The Tribunal found that ADGA ought to have fully evaluated whether it could accommodate Lane's disability-related needs without undue hardship.

An employer's assessment must not be based on fears, myths or stereotypes; rather, it must be based on credible and objective evidence. The rigorous application of these protections ensures the inclusion of employees with mental health issues.

\section{E. Requiring Treatment Compliance}

Employers may be reluctant to continue to employ a person who refuses treatment. A well-meaning manager may attempt to coerce an employee to access psychiatric services even under threat of job consequence. This type of accommodation is not inclusive, and ultimately stands in the way of the equality project. Voluntary accommodation is most consistent with the dignity interest of the person being accommodated.

Some case law has established that the failure to follow medical treatment, including failure to take prescribed medications, may result in a dismissal being upheld. ${ }^{147}$ In C.A.W. 80 v Honeywell, an employee was dismissed following verbal outbursts and episodes of physical violence. ${ }^{148}$ She had been diagnosed with schizophrenia and had refused to take her medication despite the employer's efforts. The arbitrator found that while the employee had a right to refuse medical treatment, this resulted in an undue risk to the workplace.

Some employers may request evidence of continued compliance with medication from an employee returning to work after a mental health related absence. ${ }^{149}$ This usually entails the presentation of a letter from her physician. In Code Electric $v$. International Brotherhood of Electrical Workers, the employer requested an extensive report, establishing fitness to return to work, from the grievor's physician. ${ }^{150}$ The grievor argued that such a request is itself discriminatory. The arbitrator found that the employer had discharged her duty to accommodate to the point of undue hardship. The arbitrator ordered the employee's return to work only

145 Ontario Human Rights Commission, "Duty to Accommodate Mental Health Disability Upheld by Landmark Ontario Human Rights Decision” (December 18, 2007) online: OHRC

<http://www.ohrc.on.ca/en/resources/news/lane> (last accessed: 20 August 2008).

146 Lane, supra note 99.

147 CAUT, supra note 117 at 5.

148 C.A.W. 80 v Honeywell, [2002] 70 C.L.A.S. 104 (Canada Labour Arbitration).

149 Payne \& Fenton, supra note 123 at 25 . The authors relied on caselaw to assert that "[f]ailure to follow medical treatment, especially failure to take prescribed medications may result in a dismissal being upheld."

150 Code Electric Products Ltd. v International Brotherhood of Electrical Workers, Local 258 (Kinder Grievance), [2005] B.C.C.A.A.A. No. 14 (British Columbia Collective Agreement Arbitration). 
on the condition that the grievor adhere to his prescribed treatment plan. The arbitrator also authorized the employer to contact the psychiatrist if there were signs of relapse.

Employer requirements for proof of medication compliance entrench an understanding of mental health as an issue of individual accountability, and that a person with a mental health issue ought just to "pull herself up by her bootstraps." In Code Electric, the employer wrote the following letter to the employee's union:

We will not tolerate Clayton's lengthy absences from the workplace any longer. To our mind, these absences have been triggered by Clayton's own misconduct, and the time has come to say enough is enough. Clayton must demonstrate he is responsible or his employment will be terminated. ${ }^{152}$

The hostile language of the employer's letter and the arbitrator's support for dismissal suggest that "irresponsible" employees who refuse their medication are excluded from equality protections, through the operation of the undue hardship analysis.

Other tribunals have found that the refusal to follow psychiatric treatment, including medication compliance amounts to "undue hardship." In Re: York Region Board of Education a high school teacher refused to continue prescribed medication to control his mental health issues. ${ }^{153}$ As a result, he demonstrated inappropriate behaviour towards students, colleagues and parents. The Arbitration Board refused to reinstate the teacher:

...[A]fter considering the grievor's conduct, and his underlying medical condition, we determine that there was cause for disciplining the grievor, in that he was the author of his own misfortune by going off Lithium when he knew, or ought to have known, that it might negatively affect his behaviour and adversely affect his teaching situation. ... [I]t is our view that the grievor has simply waited too long to accept proper medical advice and to seek accommodation. ${ }^{154}$

If an employee with a mental health issue refuses treatment, an employer must decide whether alternatives can be found to protect workplace health and safety. ${ }^{155}$ The Ontario Human Rights Commission states that if a person with a disability wishes to take on some degree of risk that this may be acceptable provided she is fully informed of the risk and there is no risk to anyone else. ${ }^{156}$ She is not entitled

\footnotetext{
151 See also AFG Industries Ltd. and Aluminium, Brick and Glassworkers International Union, Local 259 (1997), 68 L.A.C. (4th) 129 (Ontario Labour Arbitration).

152 Code Electric, supra note 151 at para 41 (emphasis added).

153 Re: York Region Board of Education (2000), 84 L.A.C. (4 $\left.4^{\text {th }}\right) 90$ (Ontario Labour Arbitration).

154 Ibid at $103 f f$ [emphasis added].

155 Duty to Accommodate, supra note 25 at 27.

156 OHRC Fact Sheet, supra note 44.
} 
to assume a real and serious risk if there is a demonstrable risk of substantial harm to anyone related to her treatment refusal. ${ }^{15}$

The decision of Re: York Region Board of Education undoes positive efforts toward the inclusion of workers with mental health issues. It emphasizes the medical nature and treatment of the mental health issue. ${ }^{158}$ While it does engage the language of accommodation, it additionally requires employees to accept "proper medical advice." It proposes that it amounts to an undue hardship for an employer to accommodate persons with mental health issues who refuse medication.

A person with a mental health issue may not have insight into her disability and her need for treatment. She may not have the capacity to make treatment decisions even if she has not been legally determined as "incapable." Situations may not have arisen that necessitated the examination of her capacity to make treatment decisions. She should not be refused human rights protection for refusing treatment, where she was not capable of making the decision to refuse treatment.

The York decision assumes that it is unreasonable to refuse pharmacological intervention, despite legitimate concerns about the safety and effectiveness of antidepressants and neuroleptics (consider recent reports about Champix and Paxil). The side effects of some psychotropic medications can be severe and include hypertension, fatigue, nausea and tremors. If a person with a mental health issue has insight into their medical condition and has the capacity to make treatment decisions, it may be a reasonable decision for that person to refuse medication.

\section{F. Workplace Harassment of an Employee with a Mental Health Issue}

Harassment is a form of discrimination that includes behaviour or comments that insults or offends another person based on a ground set out by the Code. ${ }^{159}$ Harassment can be overt, taking the form of jokes, rudeness and physical intimidation. It can also be subtle, involving social ostracism and exclusion. Harassment can also take the form of "mobbing," the ongoing and systematic bullying by co-workers. According to the Canadian Association of Mental Health, mobbing is particularly common where an employee has a mental health issue. Because mental health issues are often "invisible," co-workers may not understand that the employee's behaviour is disability-related. In addition, because people with mental illnesses are often stigmatized as lazy, incompetent or violent, many coworkers feel justified in treating them in a negative manner. ${ }^{16}$

An employee with a mental health issue may be reluctant to report incidents of harassment and may fear reprisal. She may fear disclosure of her disability if the employer is not already aware of it, for fear of negative job consequences. The experience of harassment may delay recovery by eroding the self-confidence and self-esteem of the employee. A British study found that one third of respondents

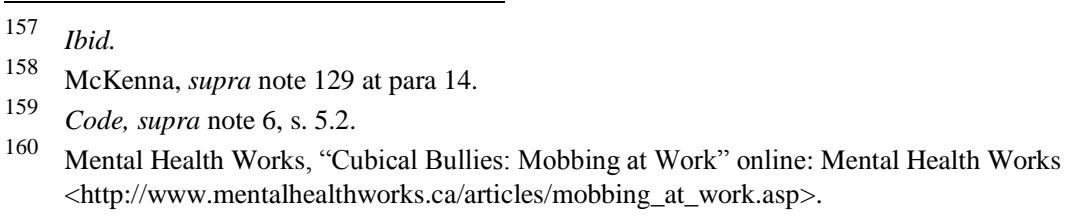


believed that bullying at work contributed to their mental health issues. ${ }^{16}$ Harassment and bullying can exacerbate mental health issues, resulting in a vicious cycle of increased harassment.

This area of law is unsettled, and there is little case law to provide guidance to human rights tribunals. In Fendick v. Lakes District Maintenance Ltd., the employer was found not to have accommodated a worker with depression and anxiety. ${ }^{162}$ However, the Tribunal ruled that the complainant had not established a prima facie case of harassment. During lunch, one or two employees went into the manager's office and found the complainant's evaluation and, subsequently, read it aloud to other employees in the lunchroom. Although he may have been subjected to harassment, the Tribunal found that the harassment was not linked to his disability:

Work places can be "rough and tumble" environments, and not all managers are experts in human relations, but these matters do not constitute discrimination unless it can be tied to a prohibited ground under the Code. ${ }^{163}$

The province of Quebec has enacted legislation to protect workers against mobbing. ${ }^{164}$ Without a broader and nuanced understanding of harassment, courts and tribunals will continue to prevent the inclusion of workers with mental health issues in the workplace and beyond.

\section{G. Discriminatory Attitudes of Customers or Coworkers}

An employer may attempt to justify her conduct, by blaming the discriminatory attitudes of customers or co-workers. However, hostility or resentment from other co-workers and customer "preferences" are expressly excluded from consideration in the accommodation process. ${ }^{165}$ In Bernard v. Waycobah Board of Education, the complainant was a receptionist at a school. She alleged that her employment was terminated because of behaviour associated with her mental health issues. The Board of Education argued that parents threatened to withdraw students from the school if the complainant was not dismissed. The Tribunal found that the Board of Education may not justify its own conduct by blaming the parents' threats, which were based on discriminatory grounds. To support this, the Tribunal cited Beatrice Vizkelety:

161 Mental Health Foundation, Out at Work; A Survey of the Experience of People with Mental Health Problems within the Workplace, (London: Mental Health Foundation, 2002).

Fendick v Lakes District Maintenance Ltd., [2005] B.C.H.R.T.D. No. 573 (British Columbia Human Rights Tribunal). Fendick confirmed the employer's duty to make inquiries about the employee's undisclosed need for accommodation. The employer defended the claim against it, asserting that it did not know of the employee's condition. The Tribunal ruled that they "knew enough to oblige it to make inquiries" and that "it is not necessary for all levels of management to know about the need for accommodation."

163 Ibid at para 171 [emphasis added].

164 An Act Respecting Labour Standards, R.S.Q. 1994, c.N 1-1, s.81.18. Section 81.18 sets out that “...'psychological harassment' means any vexatious behaviour in the form of repeated and hostile or unwanted conduct, verbal comments, actions or gestures, that affects an employee's dignity or psychological or physical integrity and that results in a harmful work environment for the employee." 
It happens that respondents will try to justify unequal treatment by blaming "others" for their actions, but, where they do, the discrimination is no less real and apparent. Moreover, the objections of these "others" - assuming they are real - may themselves be founded upon prejudice or stereotypes. ${ }^{166}$

A complaint from a person with a physical disability, Hajla v. Nestoras and Welland Plaza Restaurant stands for the proposition that customer preference may not justify discriminatory conduct by the employer. A woman who had epilepsy was denied entry to a restaurant because the restaurant owner feared he would lose customers if the complainant continued to frequent the restaurant. The Tribunal offered the following assessment:

...[I]t is well established that it cannot be a defense of a respondent to assert that he only discriminated because of the perceived or real preferences of customers. There are many decisions which have held that it is not a defense to say that one discriminated as a matter of business or economic advantage or necessity, to meet the wishes of other persons, such as customers, tenants or employees. ... More generally put, one cannot break the law because another person wants or encourages the transgressor to do so. ${ }^{167}$

Where an employer attempts to justify negative treatment of an employee with a mental health issue, it must be clear that discriminatory customer preferences must not be considered in the measure of undue hardship.

\section{CONCLUSION}

Large-scale employers are beginning to address mental health issues in the workplace, understanding that it makes business sense to do so. ${ }^{168}$ Employers are increasingly aware of the effect of stress and depression on performance and productivity. ${ }^{169}$ The employer is responsible for maintaining a workplace that is free from discrimination. ${ }^{170}$ The accommodation of persons with mental health

166 Beatrice Vizkelety, Proving Discrimination in Canada (Toronto: Carswell, 1987) at 137.

167 Hajla $v$ Nestoras and Welland Plaza Restaurant (1987), 8 C.H.R.R. D/3879 (Ontario Board of Inquiry) [emphasis added].

168 Great West Life Assurance Company, "Mental Health Facts and Figures: Why Mental Health Matters in the Workplace" online: Great West < http://www.great-west-life.com/001/c-mh/centre-for-mental-health/FactsandFigures/index.htm $>$.

169 Natacha Joubert \& Thomas Stephens, "The Economic Burden of Mental Health Problems in Canada" (2001) 22 Chronic Diseases in Canada 18, online: Public Health Agency of Canada <http://www.phac-aspc.gc.ca/publicat/cdic-mcc/22-1/d_e.html>. Research indicated that mental health issues lead to lost productivity and health-care expenditures totaling at least $\$ 14.4$ billion per year. The estimated burden places mental health problems among the costliest conditions in Canada.

170 Ontario Human Rights Commission, "Human Rights at Work" (Toronto: Government of Ontario, 2004) online: OHRC < http://www.o-h-r- c.on.ca/en/resources/Guides/ H-R-at-Work?page=HRatWork.html>. The Ontario Human Rights Commission stated that "[a]n employer who knew of, 
issues requires creative and flexible accommodations by employers. ${ }^{171}$ Since the duty to accommodate is an "individual remedy," there is no firm list of accommodations. ${ }^{173}$ The workplace environment may be modified by, for example, providing a quiet place to work without outside distractions. Employers should offer clear and specific directions and instructions for tasks assigned. Employers may offer work flexibility including: early or late starts, working from home, frequent breaks, shift changes and provisions for banking overtime. Large workplaces may be able to offer employees a similar job in a different department in the case of workplace harassment. Large companies may also be able to offer to tailor job descriptions suited to the employee's abilities. Employers should make arrangements for crisis intervention in order to address mental health symptoms quickly as they arise.

In order to prevent discrimination in the first instance, employers should develop clear policy statements prohibiting discrimination. Policies should provide for ongoing training to employees, develop grievance procedures and establish investigation procedures. While accommodation decisions must be made on a case-by-case basis, using general policies as a starting point simplifies the accommodation process. Policies, which set out possible accommodation options, offer clarity to employees and potential employees. Anti-discrimination principles should infuse all workplace policies and be reviewed periodically to meet changing needs. The development of anti-discrimination policies at the outset is critical; this preventative approach is cheaper and more effective than having to design policies after an incident of suspected discrimination. The cost of "retrofitting" accommodations is greater than if anti-discrimination policies are built into business practices at the outset.

Focusing on solutions around mental health issues in the workplace will benefit employers and employees alike. While employers may balk at the perceived high cost of accommodating employees with mental health issues, clearly any sort of accommodation would have a cost. The cost of providing mental health related accommodations is fairly low, and in many cases is less than $\$ 500 .{ }^{174}$ One study found an annual savings of up to $\$ 10,000$ per employee when the employer provided prescription drug benefits, sick leave, and wage replacement schemes. ${ }^{175}$ The benefits of workplace accommodation include

or should have had knowledge of, the harassment and could have taken steps to prevent or stop it, may also be liable in a human rights complaint. A person who has the authority to prevent or discourage harassment may be found responsible or 'vicariously liable'."

171 Oak Bay Marina Ltd. (c.o.b. Painter's Lodge) v British Columbia (Human Rights Commission) (2002) 217 D.L.R. (4th) 747 at para 22. The Court of Appeal found that "[t]he application of the law regarding accommodation presents particular challenges where the disability is not a physical one but a mental one..."

172 Mental Health Works, Rights and Responsibilities, online; Mental Health Works <http://www.mentalhealthworks.ca/employers/faq/question7.asp>.

173 CAUT, supra note 117 at 8 . The author noted: "Accommodations for mental disabilities must be approached on a case-by-case basis... [Personnel] must work with the employee and the union to come up with creative and flexible solutions to workplace barriers."

174 Kendra Duckworth, "Accommodation and Compliance Series: Employees with Psychiatric Impairments", online: Job Accommodation Network <http://www.jan.wv u.edu/media /Psychiatric.html>.

175

Honourable Michael Wilson, Russell Joffe \& Bill Wilkerson, The Unheralded Business Crisis in Canada: Depression at Work - An Information Paper for Business, Incorporating "12 Steps to a 
increased productivity, shorter stress leaves, reduced long-term disability claims and improved workplace relations.

Inclusion is a primary goal of equality protections and is central to the pursuit of equality, independence and full participation in social, work and community life. Equality rights must protect against the multifarious effects of exclusion and facilitate a sense of belonging in the workplace. Where disability-related needs impact an ability to complete workplace duties, a person with a mental health issue may require accommodation. Accommodation must assist in the gaining and maintaining of employment for people with mental health issues. Managers must include employees with mental health issues in decision-making about accommodation options. Equality protections must be forward thinking, fostering a sense of belonging in the universal community.

Business Plan to Defeat Depression" (Toronto: Global Business and Economic Roundtable on Addiction and Mental Health, 2000), online: Mental Health Roundtable <www.mental-healthroundtable.ca/aug_round_pdfs/Roundtable\%20report_Jul20.pdf $>$ at 4,19.

176 Mental Health Works, supra note 19 at 1. 
